\title{
... From the Editor's Bookshelf
}

\author{
JOURNALS
}

Human Studies

Editor: George Psathas, Dept. of Sociology, Boston University, Boston, MA 02215

Journal of Phenomenological Psychology

Editor: Amedeo Giorgi, Psychology Dept., Duquesne University, Pittsburgh, PA 15282

Phenomenology and Pedagogy

Editor: Max van Manen, Faculty of Education, University of Alberta, Edmonton, Alberta, CANADA

Review of Existential Psychology and Psychiatry

Editor: Keith hoeller, Philosophy Dept.,

Seattle University, Seattle, WA 98122

RECENT BOOKS

Aanstoos, C. M. (Ed.). (1984). Exploring the lived world: Readings in phenomenological psychology. Volume 23 of the annual series: west Georgia College Studies in the Social Sciences. Carrollton: West Georgia College.

de Koning, A. J. \& Jenner, F. A. (Eds.). (1982). Phenomenology and psychiatry. New York: Grune \& Stratton.

Giorgi, A., Barton, A., \& Maes, C. (Eds.). (1983). Duquesne studies in phenomenological psychology (Vol. 4). Pittsburgh: Duquesne University Press.

Klee, J. (1982). Points of departure: Aspects of the Tao. South Bend: And Books.

Laing, R. D. (1982). The voice of experience. New York: Pantheon Books.

Polkinghorne, D. (1983). Methodoloay for the human sciences: systems of inquiry. Albany: SUNY Press.

Pollio, H. R. (1982). Behavior and existence: An introduction to empirical humanistic psychology. Monterey: Brooks/Cole.

Romanyshyn, R. D. (1982). Psychological life: From science to metaphor. Austin: University of Texas Press.

Valle, R.S. \& Von Eckartsberg, R. (Eds.). (1981). The metaphors of consciousness. New York: Plenum Press.

THE HUMANISTIC PSYCHOLOGIST 35 VOL. 13, NO. 1, WINTER 1985 